\title{
The design and implementation of a longitudinal social medicine curriculum at the University of Vermont's Larner College of Medicine
}

Raghav K. Goyal ${ }^{\dagger}$, Christina A. Dawson ${ }^{\dagger}$, Samuel B. Epstein ${ }^{\dagger}$, Richard J. Brach, Sheridan M. Finnie, Karen M. Lounsbury, Timothy Lahey ${ }^{*}$ and Shaden T. Eldakar-Hein

\begin{abstract}
Background: Despite an abundant literature advocating that social determinants of health (SDH) be taught during undergraduate medical education, there are few detailed descriptions of how to design and implement longitudinal core curricula that is delivered to all students and accomplishes this goal.

Methods: In this paper, we describe the design and implementation of a social medicine curriculum at the University of Vermont's Larner College of Medicine (UVM Larner). Using Kern's principles, we designed a longitudinal curriculum that extends through both preclinical and clinical training for all students and focused on integrating SDH material directly into basic science and clinical training.

Results: We successfully developed and implemented two primary tools, a "Social Medicine Theme of the Week" (SMTW) in preclinical training, and SDH rounds in the clinical setting to deliver SDH content to all learners at UVM Larner.
\end{abstract}

Conclusions: Extensive student-faculty partnerships, robust needs assessment, and focusing on longitudinal and integrated SDH content delivery to all students were key features that contributed to successful design and implementation.

Keywords: Social determinants of health, Medical education, Undergraduate medical education, Preclinical medical education, Clinical medical education, Health care, Racism, Health inequities

\section{Background}

Social determinants of health (SDH) influence innumerable patient care outcomes from health care expenditures to life expectancy and professional satisfaction [1-5]. Physician educators are motivated to implement $\mathrm{SDH}$ as a central feature of undergraduate medical education [6-14]. This

\footnotetext{
* Correspondence: Timothy.Lahey@med.UVM.edu

${ }^{\dagger}$ Raghav K. Goyal, Christina A. Dawson and Samuel B. Epstein contributed equally to this work.

University of Vermont's Larner College of Medicine, UVMMC, 111 Colchester Ave, Smith 2, Burlington, VT 05401, USA
}

training has the potential to prepare future providers to notice the $\mathrm{SDH}$, to gain tools to address them, and to reduce cognitive dissonance and "betrayals of purpose" [15] whereby SDH may exacerbate burnout through clinical productivity-driven incentives, helplessness about chronic health problems, and lack of insurance coverage $[2,16]$. Despite growing awareness of the tolls of healthcare disparities in the United States [17], significant obstacles to meaningful inclusion of SDH training in the undergraduate medical curriculum remain. These obstacles include the surfeit

(c) The Author(s). 2021, corrected publication 2021. Open Access This article is licensed under a Creative Commons Attribution 4.0 International License, which permits use, sharing, adaptation, distribution and reproduction in any medium or format, as long as you give appropriate credit to the original author(s) and the source, provide a link to the Creative Commons licence, and indicate if changes were made. The images or other third party material in this article are included in the article's Creative Commons licence, unless indicated otherwise in a credit line to the material. If material is not included in the article's Creative Commons licence and your intended use is not permitted by statutory regulation or exceeds the permitted use, you will need to obtain permission directly from the copyright holder. To view a copy of this licence, visit http://creativecommons.org/ licenses/by/4.0/. The Creative Commons Public Domain Dedication waiver (http://creativecommons.org/publicdomain/zero/1. 0/) applies to the data made available in this article, unless otherwise stated in a credit line to the data. 
of foundational science material considered necessary for medical training, diverse faculty opinions about the educational utility of teaching SDH topics, and stricter average evidentiary standards for incorporation of SDH material into the curriculum compared to what justified the inclusion of traditional foundational science material [18-20].

Building on prior publications describing creative means of incorporating SDH into undergraduate medical education [14, 21-24], and linked to relevant curriculum objectives required by the Liaison Committee on Medicine Education (LCME) such as "Societal Problems" and "Cultural Competence and Health Care Disparities" [25], we describe the design and implementation of a novel longitudinal core curriculum in social medicine at the University of Vermont's Larner College of Medicine (UVM Larner).

This social medicine curriculum (SMC) includes diverse topics related to SDH and health disparities which utilize critical reflection, the incorporation of community voices, and experiential learning as essential teaching modalities. The UVM Larner SMC is deployed longitudinally to all learners, integrated directly into both didactic and clinical training, positions students as active learners who critique the existing health care system, engages them in interprofessional education, and is robustly assessed [21, 23, 26-29].

\section{Steps in the design of a novel social medicine curriculum \\ Problem identification and needs assessment}

In 2018, a group of student advocates at UVM Larner, including the Class of 2021 student authors, were concerned that their medical education was not adequately preparing them to recognize or redress the SDH. These concerns drove the group to advocate for change. This group adopted the name Social Justice Coalition (SJC) and set out to use Kern's six steps of curricular development to advocate for change at UVM Larner [30]. Kern's process for curricular development has been used with success in various domains of medical education [3133] and offers a logical and stepwise methodology for curricular development that spans problem identification and needs assessment to implementation and evaluation.

Students initially identified the problem through firsthand experience of both preclinical and clinical curricula, which constituted their first, informal phase of needs assessment. Thereafter, students undertook a second, formal, lecture-by-lecture needs assessment which involved an analysis of slides and teaching materials.

These needs assessments led students to identify key stakeholders (Table 1). Patients are the primary stakeholders in that all efforts to teach the SDH in medical training are geared at addressing the health burdens

Table 1 Initial needs assessment and summary of stakeholders

\begin{tabular}{|c|c|}
\hline Stakeholder & Needs assessment findings \\
\hline \multirow[t]{5}{*}{ Patients } & - Central stakeholder in medical education \\
\hline & - Impacted by racism, homophobia, sexism, etc. in the clinic \\
\hline & - Impacted by rising healthcare costs and poor access to healthcare \\
\hline & - Impacted by poverty and access to preventive health resources \\
\hline & - Impacted by lack of cultural perspective, and humanism/connection in the clinic \\
\hline \multirow[t]{5}{*}{ Students } & - Understanding SDH might mitigate burnout long-term \\
\hline & - No preconceived notions about how healthcare delivery takes place \\
\hline & - Likely more versed in SDH concepts than faculty \\
\hline & - Many passionate students willing to build/develop curricula \\
\hline & - Heavy workload, already stressed about board exams and content load \\
\hline \multirow[t]{6}{*}{ Faculty/Course Directors } & - Make decisions with regards to education content and scheduling \\
\hline & - Beholden to LCME standards and administrative expectations \\
\hline & - Limited time to develop curricula due to academic and clinic responsibilities \\
\hline & - Many passionate faculty who are excited to partner with students \\
\hline & - Some resistant faculty who do not see how or why to change classical teaching \\
\hline & - Faculty can serve as learners to educate themselves about this material \\
\hline \multirow[t]{4}{*}{ Administration } & - Responsibility to ensure curricula is universal, regularly assessed, and adhering to LCME standards \\
\hline & - Many competing priorities for curricular time \\
\hline & $\begin{array}{l}\text { - A number of passionate administrators who are willing to allow students to take lead with } \\
\text { curricular development }\end{array}$ \\
\hline & - UVM Larner has created environment that is willing to adjust and change \\
\hline
\end{tabular}


faced by patients at large: disproportionate health effects on Black and Brown peoples, suicidality in transgender populations, mounting health care costs and poor insurance access, the chronic health issues created by mental illness, poverty, and poor access to resources for illness prevention, and the structural forces which cause and exacerbate substance use.

Further identification of faculty and administrators as joint stakeholders led to a targeted needs assessment phase. Key faculty, students, and course directors were invited to a series of meetings aimed at answering three key questions: Do you believe SDH is being adequately taught in the classroom? Where are the SDH currently being taught in the classroom? Where do you think there could be greater improvement of SDH education in the classroom?

This needs assessment - which we estimate took approximately $10 \mathrm{~h}$ per week for several months - yielded two results: the formalization of a team of core students and faculty committed to this work and a clear map of where SDH content was already being taught (Fig. 1).

The content map allowed us to see what was being taught and to identify gaps. There were many SDH topics that UVM Larner was already teaching: an orientation seminar about racism and bias, a first-year weekly small group discussion course called Professionalism, Communication, and Reflection (PCR), two public health lectures in the first 2 years of training, a 5 month Public Health Project with a community organization during the second year, 12 ethics lectures in the first 2 years of training, two clinical "bridge weeks" on Palliative Care and Global Health, and an annual interprofessional 4-h Cultural Awareness Conference.

The extensive needs assessment and mapping process cemented the student and faculty team and revealed key opportunities for further intervention. For example, although SDH content existed at UVM Larner, this content was separated from the foundational sciences curriculum in discrete courses, informally assessed, lacked space for critical reflection, had no centralized coordination, and lacked direct clinical integration.

\section{Goals and objectives of a social medicine curriculum}

Encouraged by how much material was already being taught, the students and faculty developed a new SDH curriculum with the goal of training a cohort of critically reflective medical students who would be prepared to see and address the complex social manifestations of health burden today. We named this improved curriculum the Social Medicine Curriculum (SMC). This term alludes to the societal and public health perspectives that traditionally fall under the banner of SDH but also emphasizes the importance of critical consciousness and humanities training as articulated in the Social Medicine Consortium's consensus statement [34].

The design of the SMC started with the development of seven broad SMC learning objectives categories (Table 2) as well as 184 related session learning objectives (Supplemental 1). These objectives were generated through student and faculty conversations and literature review.

These learning objectives focus on encouraging critical self-reflection and giving students the historical and narrative tools necessary to contextualize health disparities. The overarching goal is to improve patient outcomes by training a cohort of future physicians that is prepared to enter into a healthcare landscape that is increasingly governed by financial, political, and social forces, and to equip them with the interpersonal and narrative tools necessary to navigate this landscape to understand each patient's unique challenges in achieving their best health outcomes.

Critical self-reflection is an important tool for physicians embarking on work to redress the SDH. Being able to navigate and appraise one's own place in SDH issues such as systemic racism, housing insecurity, and homophobia for example is prerequisite to understanding material that does not have clear right or wrong answers, advocating for patients, and mitigating burnout [13, 14]. Much of our work rested on the presence of the weekly small group discussions held already in the PCR course as space for SDH-focused critical reflection.

Upon completion of the needs assessment and learning objectives, we set out to design and implement a social medicine curriculum that was critically reflective, featured community voices, was longitudinally deployed to learners, integrated directly into existing preclinical and clinical curriculum, co-championed by diverse faculty, and regularly assessed. This curricular design involved three core organizing processes: Cross-Curricular Integration, Content Generation, and Clinical Social Determinants of Health Rounds.

\section{Cross-curricular integration of preclinical training}

To highlight its central importance to undergraduate medical education, and to ensure it would be given equal curricular footing with other foundational sciences, we focused on cross-curricular integration of the SMC. This involved two main processes: (1) drawing connections between existing SM curricular elements and the foundational sciences and (2) an intervention we call the Social Medicine Theme of the Week (SMTW). For each week of the first and second years of the preclinical curriculum, we developed a Social Medicine Theme, grounded in one of our seven broad SMC learning 


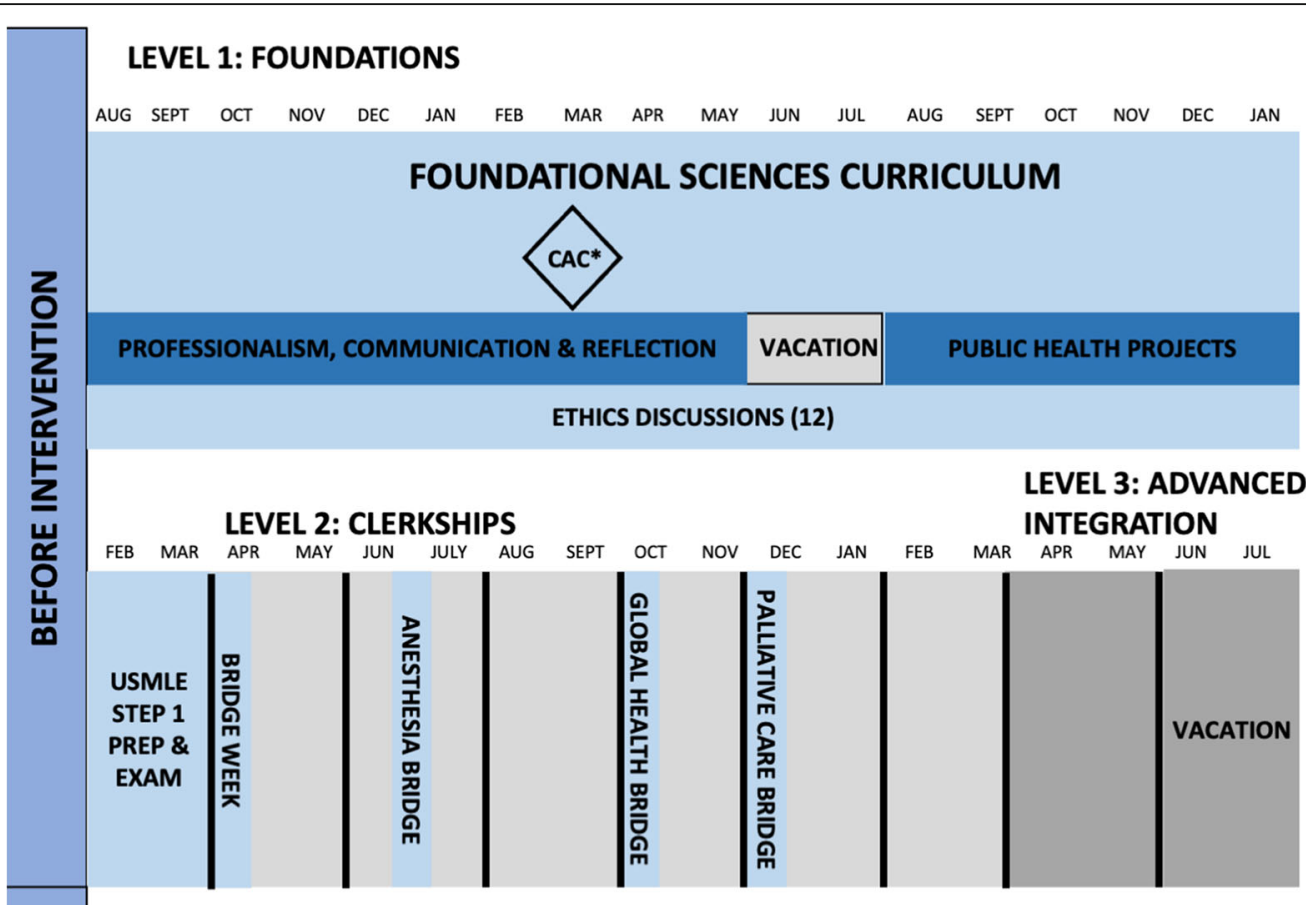

LEVEL 1: FOUNDATIONS

AUG SEPT OCT NOV DEC JAN FEB MAR APR MAY JUN JUL AUG SEPT OCT NOV DEC JAN
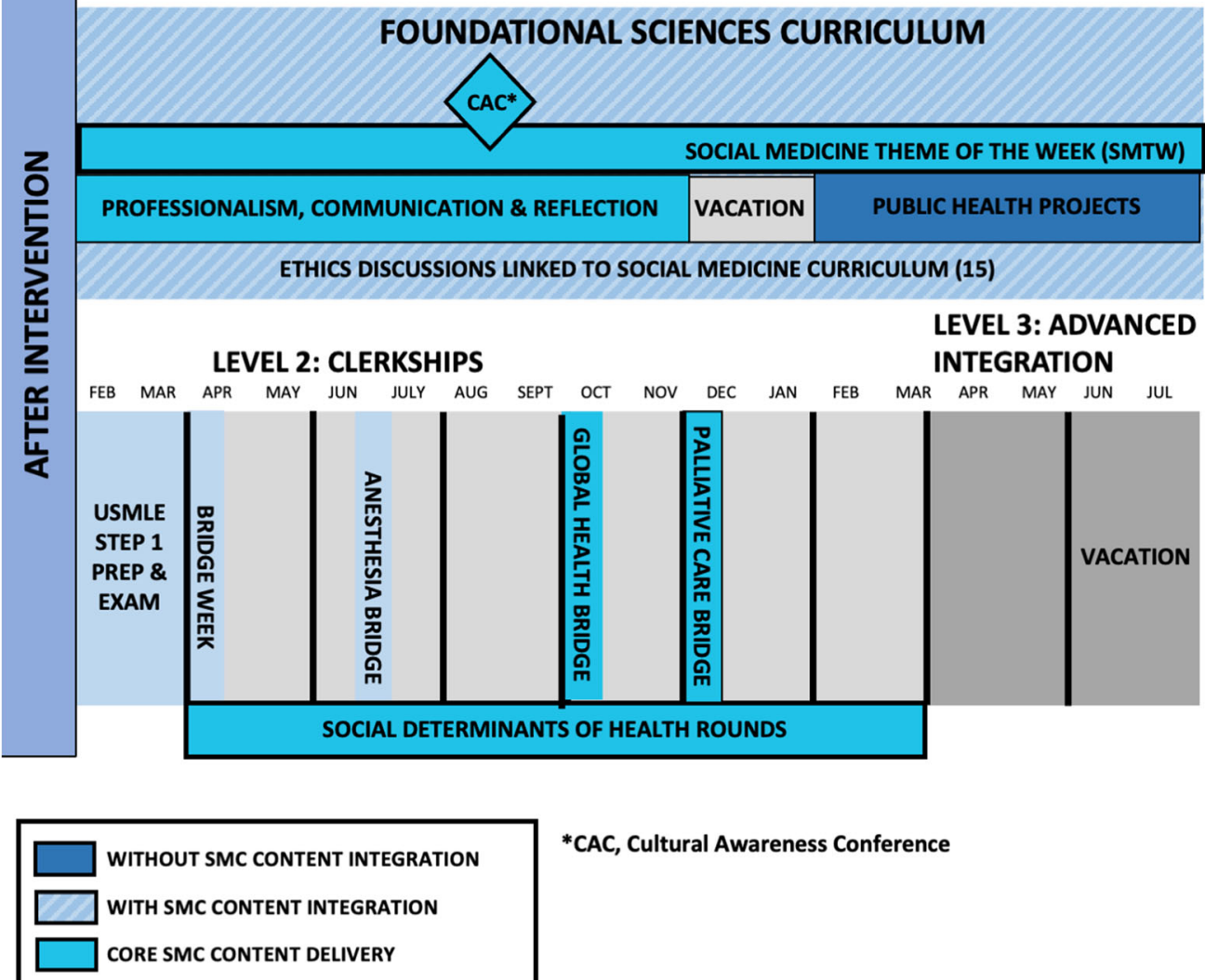

*CAC, Cultural Awareness Conference

Fig. 1 Vermont Integrated Curriculum Pre and Post Social Medicine Intervention 
Table 2 Social medicine curriculum learning objectives categories

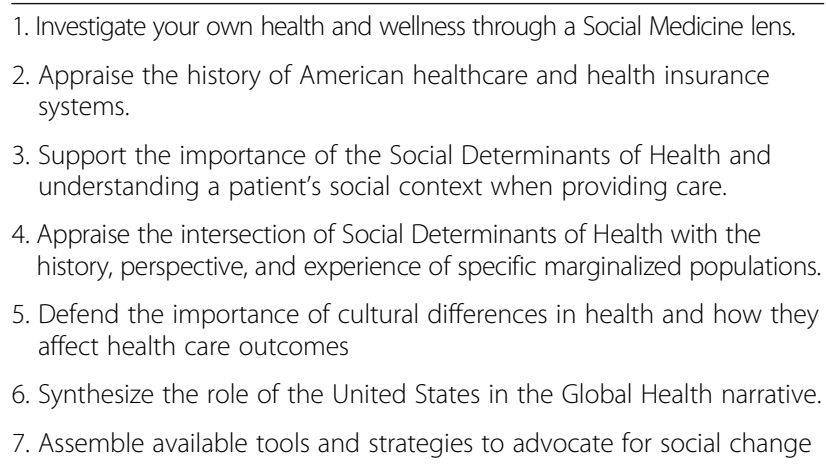

objectives categories (Table 2), and directly connected to what was being taught in the foundational science curriculum.

The creation of the SMTW allowed us to not only to draw topical connections between the foundational sciences and the SMC but also to link foundational science courses to the PCR course. This in turn allowed small groups of students to discuss and analyze SMC topics in more detail. PCR is a small group discussion course that meets for approximately 90 min weekly for the duration of the pre-clinical curriculum. Moderated by a faculty member, the course covers a broad range of topics from the role of medical interpreters, to abortion, to burnout and racism. The SMC harnessed the potential of PCR as a multidisciplinary discussion space where complicated topics could be reflectively discussed in a brave [35] and non-judgmental space.

The cross-curricular integration of SMC with foundational sciences and PCR is depicted by examples shown in Table 3. Beyond creating topical linkages between foundational sciences, PCR and the SMC, students volunteered to announce the SMTW each week to their class. This moment of student-led reflection, which typically lasts less than $5 \mathrm{~min}$, draws student attention to curricular framing, and, as appropriate, to the SMC's goal of creating future physicians who are leaders of health care change. The SMTW announcements positioned students as active leaders of the curriculum integration process. We included a reminder on students' online calendars, asked course directors to notify faculty of the SMTW, and facilitated the addition of new aligned slides or discussion questions into key sessions. This material was linked to exam questions, case studies in active learning sessions, and the SJC tied the SMTW to extracurricular events such as lunch discussions around complementary topics.

This curricular scaffolding created opportunities for course directors to incorporate SM content into existing sessions. Table 4 depicts one example of how the
SMTW created opportunities to integrate SM content directly into 1 week of basic sciences curriculum.

During this week, we established a SMTW titled "Housing and Water" based on the basic science content related to toxicology and microcytic anemias. The crosscurricular integration was realized first by the development of a new PCR session called "Environmental Health: Flint and Dakota Access" (Table 5) Then, a lecture slide was inserted into the Toxicology session about how poverty, nationality, and race make certain populations more prone to environmental harm with two associated learning objectives. Further, we posed slides into the "Clinical Decision Making" lecture that asked students to reflect on their assumptions about patient's access to housing and basic human rights based on their physical appearance in the clinical setting. This week, we also wrote two multiple choice exam questions that would appear on students' exams.

We performed an identical process as described above for each of the first- and second-year courses (first year seen in Supplement 2), with the goal of drawing connections between SM content and the basic sciences curriculum, assuring the content had a place to be discussed meaningfully and reflectively.

\section{Preclinical content generation}

The above work of cross-curricular integration allowed us to link many SDH-related topics to existing foundational science topics. Some content of the ideal SMC drafted through our needs assessment and learning objective generation was not yet covered in the existing UVM Larner curriculum, thus requiring new content generation.

One example of Content Generation was already discussed in the prior section, specifically the creation of a novel PCR session titled "Environmental Health: Flint and Dakota Access" (Table 5). Another example was during a SMTW titled "The Genetic Basis of Race." The theme was based on the week's basic science training in genetics and served to highlight eugenics and the University's historical participation in this movement. The PCR session was entitled "Eugenics and the Culture of Medicine" and can be seen in Table 6 .

When generating new content, we used diverse resources from the medical humanities such as literature, visual arts, music, podcasts, policy, and law. Throughout we featured voices from outside of medicine and paired these resources to discussion questions that fostered critical self-reflection as a means of enhancing professionalism and clinical competency as well as challenging the expectation that complex questions need to have simple answers [13, 28, 36].

During the design of the SMC, we believed it was critically important to recruit community members and other healthcare professionals into educator positions 
Table 3 Summary of cross-curricular integration of social medicine theme of the week with professionalism, communication and reflection course, foundational sciences topics and ethics

\begin{tabular}{|c|c|c|c|}
\hline $\begin{array}{l}\text { Relevant foundational science curriculum } \\
\text { topics }\end{array}$ & $\begin{array}{l}\text { Social } \\
\text { Medicine } \\
\text { Theme of } \\
\text { the Week }\end{array}$ & $\begin{array}{l}\text { Social Medicine Curriculum topic } \\
\text { addressed in Professionalism, } \\
\text { Communication and Reflection course }\end{array}$ & Ethics topics \\
\hline $\begin{array}{l}\text { Sickle cell anemia, population genetics, basics } \\
\text { of genetics }\end{array}$ & $\begin{array}{l}\text { The genetic } \\
\text { basis of race }\end{array}$ & Eugenics and the culture of medicine & $\begin{array}{l}\text { Introduction to ethics including } \\
\text { foundational bioethics values like } \\
\text { justice }\end{array}$ \\
\hline Non-mendelian genetics, gross anatomy lab & $\begin{array}{l}\text { Death and } \\
\text { dying }\end{array}$ & Cadaver, death, and dying & \\
\hline Cancer, white coat ceremony, genetics & $\begin{array}{l}\text { Power and } \\
\text { privilege }\end{array}$ & Power, privilege, and the white coat & $\begin{array}{l}\text { History of ethical violations in } \\
\text { medicine including via physician } \\
\text { disrespect for vulnerable populations }\end{array}$ \\
\hline $\begin{array}{l}\text { Distribution of "doctor bags" Annual named } \\
\text { lecture on equity (topic: Transgender health) } \\
\text { PCR spiritual care shadowing orientation }\end{array}$ & $\begin{array}{l}\text { The power of } \\
\text { listening }\end{array}$ & Narrative Medicine and visit to hospital & Solidarity with vulnerable populations \\
\hline $\begin{array}{l}\text { Cystic fibrosis, respiratory anatomy and } \\
\text { physiology, sympathetic chain }\end{array}$ & $\begin{array}{l}\text { History of } \\
\text { American } \\
\text { healthcare }\end{array}$ & Introduction to American healthcare & $\begin{array}{l}\text { Respect for patient autonomy: } \\
\text { medical decision-making, surrogate } \\
\text { decision-making and shared decision- } \\
\text { making }\end{array}$ \\
\hline Gl anatomy and physiology, gross anatomy lab & $\begin{array}{l}\text { Race and } \\
\text { food }\end{array}$ & Racism and food & Ethical approaches to race and culture \\
\hline Reproductive system anatomy and physiology & $\begin{array}{l}\text { Owning } \\
\text { bodies }\end{array}$ & Abortion and values clarification & $\begin{array}{l}\text { Abortion, physician assisted death, } \\
\text { euthanasia and approaching } \\
\text { disagreements about topics in } \\
\text { medicine }\end{array}$ \\
\hline Toxicology, lead poisoning & $\begin{array}{l}\text { Housing and } \\
\text { water }\end{array}$ & $\begin{array}{l}\text { Case studies in environmental health (Flint, } \\
\text { Michigan, Dakota Access, climate change) }\end{array}$ & $\begin{array}{l}\text { Decision support for wise resource } \\
\text { allocation }\end{array}$ \\
\hline Anticoagulants & $\begin{array}{l}\text { The } \\
\text { economics of } \\
\text { healthcare }\end{array}$ & $\begin{array}{l}\text { Doctors and money, pharmaceutical } \\
\text { pricing, and cost to patients }\end{array}$ & $\begin{array}{l}\text { Health care system ethics, wise } \\
\text { allocation of transplanted organs }\end{array}$ \\
\hline Virology, HIV & $\begin{array}{l}\text { The AIDS } \\
\text { crisis }\end{array}$ & History of the AIDS epidemic & \\
\hline $\begin{array}{l}\text { Microbiome, chronic diarrhea, micronutrients, } \\
\text { parasites }\end{array}$ & $\begin{array}{l}\text { Domestic } \\
\text { access to } \\
\text { food and } \\
\text { water }\end{array}$ & $\begin{array}{l}\text { American food policy, mapping of } \\
\text { Burlington, Vermont, food deserts }\end{array}$ & \\
\hline Food as medicine, lipids & $\begin{array}{l}\text { Stigma and } \\
\text { sexuality }\end{array}$ & $\begin{array}{l}\text { Sexuality and medicine ( } \mathrm{W} / \text { body image } \\
\text { and medicine) }\end{array}$ & Sexual health ethics \\
\hline Brain tumors & $\begin{array}{l}\text { The } \\
\text { mythology of } \\
\text { the physician }\end{array}$ & $\begin{array}{l}\text { Burnout \& self-Care (+ cultural perceptions } \\
\text { of doctors, internal perceptions of doctors, } \\
\text { competition, workaholism, etc.) }\end{array}$ & Wellbeing and ethics \\
\hline History of opioids & $\begin{array}{l}\text { Addiction, } \\
\text { stigma, } \\
\text { recovery }\end{array}$ & Doctors, substance abuse, \& recovery & \\
\hline Parkinson's, tremor, Huntington's & $\begin{array}{l}\text { Aging and } \\
\text { bias }\end{array}$ & Ageism and social isolation & \\
\hline
\end{tabular}

[21]. Prior to our intervention, PCR already featured a number of sessions that featured diverse voices including nurses, physicians dealing with substance use, refugee interpreters, transgender community members, and others. Such opportunities to transform community members with complex lived experience into educators is an essential element of humanizing SM content, revealing how issues like poverty, substance abuse, racism, and homophobia truly impact health [37].
New content generation ultimately led to the creation and/or revision of 17 PCR sessions as well as the revision of two Public Health lectures, a substantive redesign of a dozen ethics sessions in the Foundations of Clinical Sciences course, the creation of dozens of small group discussion questions for the foundational science first-year courses, and hosting a variety of extracurricular lunch-time sessions on current events. 
Table 4 Snapshot of Social Medicine Theme of the Week (SMTW): housing and water

\begin{tabular}{|c|c|c|}
\hline Classroom sessions & Activity Type & Social Medicine Curriculum Intervention \\
\hline PCR: "Case Studies in Environmental Health" & Small group Session & Creation of new PCR session. See List 2. \\
\hline Orientation session & Lecture & Course director introduced the SMTW and summarized its relevance \\
\hline Introduction to Clinical Decision Making & Small group Session & $\begin{array}{l}\text { Addition of new lecture slides acknowledging social determinants of health in } \\
\text { clinical decision making, addition of new group discussion questions. }\end{array}$ \\
\hline Hematopoiesis & Lecture & None \\
\hline Heme, Globin, and RBC Maintenance & Case-based Learning & None \\
\hline Introduction to Anemia & Case-based Learning & None \\
\hline Anemia of Decreased Production & Case-based Learning & None \\
\hline Anemia of Decreased Red Cell Survival & Case-based Learning & None \\
\hline Toxicology & Case-based Learning & $\begin{array}{l}\text { Case Study: Flint Michigan, addition of new prework material, objectives, and } \\
\text { readiness quiz questions }\end{array}$ \\
\hline Introduction to Hemostasis & Lecture & None \\
\hline Hemostasis & Team-Based Learning & None \\
\hline Anemia & Small group Session & $\begin{array}{l}\text { Addition of discussion questions addressing environmental exposures and social } \\
\text { determinants of health resulting in anemia }\end{array}$ \\
\hline Week 1 Formative Quiz & Formative Quiz & $\begin{array}{l}\text { Addition of multiple-choice questions addressing Flint case study, social } \\
\text { causes/consequences of anemia }\end{array}$ \\
\hline
\end{tabular}

A clinical social medicine curriculum: preliminary stages Clinical integration of SDH training is an essential feature of any undergraduate medical curriculum [21]. The clinical environment offers students the opportunity to see the reality of how SDH principles impact patient lives.

Table 5 PCR session on case studies in environmental health

\begin{tabular}{l} 
Relevant Basic Sciences Material: Introduction to toxicology, \\
microcytic anemia \\
\hline PCR Learning Objectives \\
1. Explore the role of our healthcare system in mediating \\
environmental health issues. \\
2. Explore the responsibilities a physician has in addressing health \\
concerns with environmental underpinnings. \\
3. Examine which populations of people are more vulnerable to \\
environmental exposures. \\
PCR Readings/Resources \\
1. "Everything Water Touches," (Video, https://vimeo.com/158843832) \\
2. "Flint's Fight for American Children," (Video, https://www.youtube. \\
com/watch?v=pJQvNbYeSws) \\
3. "DAPL and American Indian as 'Protector'," (Article, https://medium. \\
com/hindsights/https-medium-com-hindsights-in-hindsight- \\
american-indian-as-protector-8f1 1a325dab7). \\
PCR Discussion Questions \\
1. What are the Structural/Social Determinants of Health that might \\
lead to lead poisoning? \\
2. What are some long-term social impacts that lead poisoning can \\
have on communities and families? \\
3. What is the role of a physician in responding to acute lead \\
poisoning? \\
4. Who is most vulnerable to environmental exposures, both \\
nationally and internationally?
\end{tabular}

Based on our initial needs assessment we noticed the same issues with $\mathrm{SDH}$ training in the clinical environment: the content was sparse, separated from the rest of the curriculum, and informally assessed.

To address these shortcomings, we performed a literature review to look for tools that could be used to deliver SDH training in the clinical environment. Interventions included those that did not directly relate to caseload in clinical environment [36, 38, 39] such as teaching kitchen approach [20], which demonstrated that experiential cooking and nutrition education improved trainees' abilities to counsel patients on diet and nutrition. In addition, the review revealed a number of approaches that focused on a select cohorts of students [21, 22, 40-42]. Ultimately, we turned to a Longitudinal Integrated Curriculum which focused on using a rounds based technique [43] that required students actively reflect on how the SDH impact their patient caseload, and to create space for students to discuss these issues with peers and faculty.

With this framework in hand, students and faculty met with clerkship directors to elaborate the intervention to their particular contexts. SDH rounds are currently in an early implementation phase in the Psychiatry and OB/GYN clerkships. Discussion with other clerkship directors is currently ongoing.

\section{Discussion}

In response to national mandates to prepare physicians to resist racism and other forms of injustice in medicine, and following a local institutional needs assessment 
Table 6 P CR session titled "Eugenics and the culture of medicine"

\begin{tabular}{|c|}
\hline etics \\
\hline PCR Learning Objectives \\
\hline $\begin{array}{l}\text { Discuss how what is condoned and promoted within the culture of } \\
\text { medicine is in a constant state of social reevaluation. }\end{array}$ \\
\hline $\begin{array}{l}\text { 2. Understand the history of eugenics at the University of Vermont } \\
\text { and in the state of Vermont. }\end{array}$ \\
\hline $\begin{array}{l}\text { 3. Understand the genetics of race and how it has been used to } \\
\text { justify mistreatment. }\end{array}$ \\
\hline 4. Examine communication in the context of medicine. \\
\hline PCR Readings/Resources \\
\hline $\begin{array}{l}\text { 1. Description of eugenics in Vermont: http://www.uvm.edu/ } \\
\text { |kaelber/eugenics/NTNT.html }\end{array}$ \\
\hline 2. Passage from "Breeding better Vermonters" by Nancy Gallagher \\
\hline $\begin{array}{l}\text { 3. Donald Berwick's article, "The epitaph of profession": https://www. } \\
\text { ncbi.nlm.nih.gov/pmc/articles/PMC2629825/ }\end{array}$ \\
\hline $\begin{array}{l}\text { 4. Description of the Eugenics Survey in Vermont: http://www.uvm. } \\
\text { edu/ eugenics/famstudiesf.html }\end{array}$ \\
\hline PCR Sample Discussion Questions \\
\hline $\begin{array}{l}\text { 1. What is the definition of race? Is race genetically acq } \\
\text { has science/genetics been used to justify mistreatme }\end{array}$ \\
\hline 2. Who are the Abenaki people? \\
\hline 3. How has medicine and the practice of medicine changed over time? \\
\hline 4. Where does science end and social perception begin? \\
\hline $\begin{array}{l}\text { 5. How is the history of eugenics at Vermont a useful way to think } \\
\text { about how cultural expectations of the role of medicine are } \\
\text { constantly changing? }\end{array}$ \\
\hline $\begin{array}{l}\text { a. Are there things that are currently happening in medicine today } \\
\text { that might seem problematic with the benefit of hindsight? }\end{array}$ \\
\hline $\begin{array}{l}\text { 6. History of medicine and doctors is one of silencing different types } \\
\text { of people and instituting certain types of people, white men in } \\
\text { suits, as physicians and silencing others }\end{array}$ \\
\hline $\begin{array}{l}\text { 7. Do you know of any other examples of the institution of medicine } \\
\text { causing more harm than good? }\end{array}$ \\
\hline 8. Is forced sterilization ever justified? \\
\hline $\begin{array}{l}\text { 9. How is the inequitable distribution of resources in the healthcare } \\
\text { system similar to the eugenics movement? }\end{array}$ \\
\hline $\begin{array}{l}\text { 10. How do modern attempts to interfere with genetics resemble or } \\
\text { not resemble eugenics movements of the past? }\end{array}$ \\
\hline
\end{tabular}

informed by national literature of social medicine, we created a social medicine curriculum at UVM Larner by drafting 184 SMC learning objectives housed in seven overarching categories, devising the SMTW as an effective platform for cross-curricular integration, generating new curricular content, and using SDH rounds to integrate this content into the clinical environment.

This work aimed to train students to recognize and redress the SDH in a fashion that utilized existing resources, focused on teamwork, and could offer a practical process that could be generalizable to other institutions. Key lessons learned during the creation of the UVM Larner SMC include the pivotal importance of small group critical reflection on SMC content, the strategic importance of extensive faculty engagement, the value of longitudinal curricular integration extending into clinical training, and initial reflections on SMC assessment $[21,24]$.

When revising or creating new sessions for the SMC, we focused on opportunities for students to develop skills in critical reflection. Critical reflection is essential to SDH training in that it encourages students to centralize their own role in health inequity, reflect on burnout, and to understand that forces like poverty, racism, patriarchy, and climate change are human-made forces without clear solutions [14].

The already existing Professionalism, Communication, and Reflection (PCR) course at UVM Larner created space for critical reflection and served as the foundation for integration into the basic science curriculum. Our initial needs assessment and onboarding of faculty and administrators identified the potential of PCR in our work, and established allies who would allow us to expand and grow it. Institutions that do not have a comparable longitudinal reflection course might struggle to generalize our work to their institution, but the needs assessment and faculty engagement that led us to PCR could yield alternative opportunities.

Faculty support and involvement as stakeholders has been the central reason for our success. Course directors, administrators, and faculty leadership have provided invaluable feedback and mentorship through every phase of design and implementation, they performed tasks that would have been impossible for students, including speaking directly with lecturers, posting SMTW announcements weekly in the students' online calendars, and keeping students apprised of logistical concerns. After the initial cohort of students has graduated, faculty members can ensure the curriculum continues, and that lessons in implementation are not forgotten between class years. Our collaborations reinforced our belief that much of this work needs to be driven by faculty and staff with content expertise, institutional knowledge and longevity, and tangible support for the ongoing work of curricular leadership.

Though our work began with students at UVM Larner, we believe this process could begin at other institutions with faculty. Our needs assessment and early exploration phase cemented our student and faculty team, and this process could have similar successes elsewhere.

To further support faculty, we have hosted a half-day social medicine teaching session, and one grand rounds on social medicine education. Moving forward, we plan to establish regular expert-led faculty training in facilitation skills and SDH content to ensure that small group 
discussion sessions and SDH rounds allow for reflective and nonjudgmental exploration. This form of facilitation is not a formal part of faculty training and is essential to a healthy and growing SDH curriculum. Incorporating faculty development as an integral part of the continued improvement of this curriculum will also help establish sustainability as students' involvement is transient by nature.

We attended closely to the importance of assessment in the design of the SMC, frequently assisting course directors in creation of multiple-choice exam questions that linked to SMC material. That said, reflective essays and observed performance in clinical settings may be superior to multiple choice questions in assessing understanding of social medicine material and impact on patient outcomes [22, 44, 45]. Our nascent SDH clinical rounds offer faculty the opportunity to explore topics with students, and to require students to make formal $\mathrm{SDH}$ presentations which, in the future, can be evaluated by objective standards.

Longitudinal curricular integration is a central strength of the SMTW approach to social medicine teaching. The SMTW has allowed us to pinpoint where social medicine content fits naturally into the basic science curriculum and creates efficient means to develop discussion questions, slides, and exam questions. This strategy makes social medicine feel like an integral part of medical training. Despite our integration success so far, there are still many weeks of the curriculum where the SMTW is not sufficiently integrated outside of the PCR session for that week.

The SMTW approach has also made it possible to deploy our curriculum universally to all students. The literature cites a number of models featuring SM tracks for select students [21, 22, 40-42], and although these models offer the potential of deeper training for students who are destined to become leaders in healthcare, we believe they miss an opportunity to build capacity and awareness in all future physicians.

\section{Next steps}

There are two forms of evaluation that are needed at this time: a programmatic evaluation of our work thus far), and a longitudinal evaluation to assess the impact of the curriculum on students' future practice as physicians. Does talking about racism in a small group session result in students recognizing their own role in various systems of oppression? Does it equip students with the tools to make change? Do SDH rounds give students tools to improve patient care, affect change, and reduce burnout?

Despite successes in fostering critical self-reflection and involving voices from the community in PCR, we have yet to incorporate service-learning into the curriculum, which is an essential task for any social medicine curriculum. Soon, we hope to unlock crosscurricular integration of an existing community-based course called the Public Health Project to fully harness the experiential power of service learning in the SMC [24].

In the clinical environment, we have so far succeeded in integrating $\mathrm{SDH}$ rounds into two out of eight core clerkships. We hope to continue to work with clerkship directors to explore SDH rounds as a modality for teaching Social Medicine, or to find other clinical tools that will allow students to apply a Social Medicine lens to the patients for which they care.

As essential next steps in improving our educational methods, we plan to continue to build our SMTW through preclinical training, offer expert-led faculty training, expand our clinical SDH rounds, and begin assessment of impacts on burnout, student reflections, and patient outcomes. We recognize that the clinical years offer unique challenges due to constantly changing schedules, geographic and temporal diversity, and demanding hours of training, but we believe that the use of small group sessions similar to the PCR groups featured earlier in the curriculum have potential to facilitate ongoing reflection upon clinical experiences by third- and fourth-year students.

\section{Conclusion}

We identify several major contributors to the successful design of the novel SMC at UVM Larner, including a student-led needs assessment, the Social Medicine Theme of the Week, the utilization of a year-long small group discussion space for critical reflection, the creation of SMC learning objectives, commitment to cross-curricular integration with foundational sciences, and adjunctive events such as $\mathrm{SDH}$ rounds. These processes can be generalized to other institutions with different baseline foundational science curricula and SDH-related content, and we are dedicated to ensuring durable student-faculty collaborations that empower future physicians to be effective agents of change and critical advocacy in health care. This work is not done. Next steps include curricular evaluation and faculty development. As Audre Lorde once said, "revolution is not a one-time event" [46].

\section{Supplementary Information}

The online version contains supplementary material available at https://doi. org/10.1186/s12909-021-02533-x.

Additional file 1: Supplemental 1. Full 184 learning objectives of the Social Medicine Curriculum at Larner College of Medicine.

Supplemental 2. Summary of all first year cross-curricular integration of SMTWS with PCR and Foundational Sciences. 


\section{Abbreviations}

LCME: Liaison Committee on Medical Education; PCR: Professionalism, Communication, and Reflection course; SDH: Social Determinants of Health; SJC: Social Justice Coalition at Larner College of Medicine; SMC: Social Medicine Curriculum; SMTW: Social Medicine Theme of the Week; URM: Underrepresented in Medicine; UVM Larner: University of Vermont Larner College of Medicine

\section{Acknowledgements}

We thank the student and faculty members of the Social Justice Coalition and faculty at the University of Vermont's Larner College of Medicine. This work was presented at the Mud Season Retreat in Burlington, VT in March 2019, the NEGEA in Philadelphia, PA in April 2019, and the Social Medicine Consortium in Chiapas, Mexico in June 2019.

\section{Authors' contributions}

RKG, CAD, and SBE designed the curriculum, and coordinated its implementation through faculty and other students' involvement. RJB and SMF continued to lead the intervention, worked on data acquisition and analyses on an adjacent paper, and revised the paper. KML helped implement the curriculum and mentored students throughout implementation and revised and drafted the paper. TPL helped design the curriculum, helped implement the curriculum, mentored students and led the writing of the manuscript. SHE helped lead design and implementation of the curriculum and drafted and revised the paper. All authors approved the manuscript for submission and agree to be accountable for all aspects of the work.

\section{Funding}

None.

\section{Availability of data and materials}

The datasets used and/or analysed during the current study are available from the corresponding author on reasonable request.

\section{Ethics approval and consent to participate}

The Institutional Review Board of the University of Vermont granted exemption of the study of this curricular intervention from review. Informed consent was not required because there was no experimental intervention to which students could be asked to consent.

\section{Consent for publication}

Not applicable.

\section{Competing interests}

The authors declare that they have no competing interests.

Received: 11 November 2020 Accepted: 1 February 2021

Published online: 24 February 2021

\section{References}

1. CDC. Social determinants of health: know what affects health: sources for data on SDOH. CDC. https://www.cdc.gov/socialdeterminants/data/index. htm. Accessed 16 Feb 2021.

2. Dzeng E, Wachter RM. Ethics in conflict: moral distress as a root cause of burnout. J Gen Intern Med. 2020;35(2):409-11.

3. WHO. Social determinants of health. WHO. https://www.who.int/social determinants/en/. Accessed 16 Feb 2021.

4. Borleffs JC. What is a good doctor? The impact of 'fruitful irrelevance' in medical education. Med Teach. 2009;31(5):447-8.

5. Wartman SA. The empirical challenge of 21st-century medical education. Acad Med. 2019;94(10):1412-5.

6. Afshar M, Han Z. Teaching and learning medical biochemistry: perspectives from a student and an educator. Med Sci Educ. 2014;24(3):339-41.

7. Dharamsi S, Ho A, Spadafora SM, Woollard R. The physician as health advocate: translating the quest for social responsibility into medical education and practice. Acad Med. 2011;86(9):1108-13.

8. Donohoe M, Schiff G. A call to service: social justice is a public health issue. Virtual Mentor. 2014;16(9):699-707.
9. Huddle TS. Perspective: medical professionalism and medical education should not involve commitments to political advocacy. Acad Med. 2011; 86(3):378-83.

10. Metzl JM, Roberts DE. Structural competency meets structural racism: race, politics, and the structure of medical knowledge. Virtual Mentor. 2014;16(9): 674-90.

11. Mishori R. The social determinants of health? Time to focus on the political determinants of health! Med Care. 2019;57(7):491-3.

12. Paquette E, Patel A. Doctors should care for patients and social justice. Scientific American. 2019. https://blogs.scientificamerican.com/observations/ doctors-should-care-for-patients-and-social-justice/. Accessed 16 Feb 2021.

13. Shapiro J, Coulehan J, Wear D, Montello M. Medical humanities and their discontents: definitions, critiques, and implications. Acad Med. 2009;84(2):192-8.

14. Sharma M, Pinto AD, Kumagai AK. Teaching the social determinants of health: a path to equity or a road to nowhere? Acad Med. 2018;93(1):25-30.

15. Gunderman R. For the Young Doctor About to Burn Out. Atlantic. 2014. https://www.theatlantic.com/health/archive/2014/02/for-the-young-doctor-a bout-to-burn-out/284005/. Accessed 16 Feb 2021.

16. Kalter L. Navigating the hidden curriculum in medical school: AAMC 2019. https:/www.aamc.org/news-insights/navigating-hidden-curriculum-medicalschool. Accessed 16 Feb 2021.

17. Left Out. Barriers to health equity for rural and underserved communities: Report of the Committee on Ways and MeansMajority, U.S. House of Representatives. 2020. https://waysandmeans.house.gov/sites/democrats.wa ysandmeans.house.gov/files/documents/WMD\%20Health\%20Equity\%2 OReport_07.2020_FINAL.pdf. Accessed 16 Feb 2021.

18. Hoffman BD, Barnes M, Ferrell C, et al. The community health and advocacy milestones profile: a novel tool linking community pediatrics and advocacy training to assessment of milestones-based competence in pediatric residency training. Acad Pediatr. 2016;16(4):309-13.

19. Klein MD, Kahn RS, Baker RC, Fink EE, Parrish DS, White DC. Training in social determinants of health in primary care: does it change resident behavior? Acad Pediatr. 2011;11(5):387-93.

20. Monlezun DJ, Dart L, Vanbeber A, et al. Machine learning-augmented propensity score-adjusted multilevel mixed effects panel analysis of handson cooking and nutrition education versus traditional curriculum for medical students as preventive cardiology: multisite cohort study of 3,248 trainees over 5 years. Biomed Res Int. 2018;2018:5051289.

21. Doobay-Persaud A, Adler MD, Bartell TR, et al. Teaching the social determinants of health in undergraduate medical education: a scoping review. J Gen Intern Med. 2019:34(5):720-30.

22. Mangold KA, Bartell TR, Doobay-Persaud AA, Adler MD, Sheehan KM. Expert consensus on inclusion of the social determinants of health in undergraduate medical education curricula. Acad Med. 2019;94(9):1355-60.

23. Martinez IL, Artze-Vega I, Wells AL, Mora JC, Gillis M. Twelve tips for teaching social determinants of health in medicine. Med Teach. 2015; 37(7):647-52.

24. Siegel J, Coleman DL, James T. Integrating social determinants of health into graduate medical education: a call for action. Acad Med. 2018;93(2):159-62.

25. Liaison Committee on Medical Education. Functions and structure of a medical school: standards for accreditation of medical education programs leading to the MD degree. 2020. https://lcme.org/wp-content/uploads/ filebase/standards/2021-22_Functions-and-Structure_2020-11-2.docx. Accessed 16 Feb 2021.

26. DasGupta S, Fornari A, Geer K, et al. Medical education for social justice: Paulo Freire revisited. J Med Humanit. 2006;27(4):245-51.

27. Kumagai AK, Lypson ML. Beyond cultural competence: critical consciousness, social justice, and multicultural education. Acad Med. 2009;84(6):782-7.

28. Kumagai AK, Wear D. "Making strange": a role for the humanities in medical education. Acad Med. 2014;89(7):973-7.

29. Leyerzapf H, Abma T. Cultural minority students' experiences with intercultural competency in medical education. Med Educ. 2017;51(5): $521-30$.

30. Thomas PA, Kern DE, Hughes MT, Chen BY. Curriculum development for medical education: a six-step approach. Baltimore: Johns Hopkins University Press; 2015.

31. Sweet $L R$, Palazzi DL. Application of Kern's six-step approach to curriculum development by global health residents. Educ Health (Abingdon). 2015; 28(2):138-41. 
32. Al-Ghamdi HS. A novel approach to teaching dermatology and plastic surgery in a combined module for undergraduate medical students. Adv Med Educ Pract. 2019;10:147-55.

33. Awal DH, Walker TWM, Mills C. Review of the intercollegiate surgical curriculum programme for oral and maxillofacial surgery aesthetics: are we underselling ourselves? Br J Oral Maxillofac Surg. 2019;57(9):918-22.

34. Achieving health equity this generation: the case for social medicine. Social Medicine Consortium; 2017. http://www.socialmedicineconsortium.org/ consensus-statement. Accessed 22 May 2020.

35. Ali D. Safe spaces and brave spaces: historical context and recommendations for student affairs professionals: NASPA; 2017. https:// www.naspa.org/files/dmfile/Policy_and_Practice_No_2_Safe_Brave_Spaces. pdf. Accessed 16 Feb 2021

36. Blackie $M$, Wear $D$. Three things to do with stories: using literature in medical, health professions, and interprofessional education. Acad Med. 2015;90(10):1309-13.

37. Kumagai AK, Jackson B, Razack S. Cutting close to the bone: student trauma, free speech, and institutional responsibility in medical education. Acad Med. 2017;92(3):318-23.

38. Chow CJ, Case GA, Matias CE. Tools for discussing identity andprivilege among medical students, trainees, and faculty. MedEdPORTAL. 2019;15: 10864. https://doi.org/10.15766/mep_2374-8265.10864.

39. Hsieh DT, Coates WC. Poverty simulation: experiential learning tool for teaching social determinants of health. AEM Educ Train. 2017:2(1):51-4.

40. Bakshi S, James A, Hennelly MO, et al. The human rights and social justice scholars program: a collaborative model for preclinical training in social medicine. Ann Glob Health. 2015;81(2):290-7.

41. Jones K, Blinkhorn LM, Schumann SA, Reddy ST. Promoting sustainable community service in the 4 th year of medical school: a longitudinal servicelearning elective. Teach Learn Med. 2014;26(3):296-303.

42. O'Brien MJ, Garland JM, Murphy KM, Shuman SJ, Whitaker RC, Larson SC Training medical students in the social determinants of health: the health scholars program at Puentes de Salud. Adv Med Educ Pract. 2014;5:307-14.

43. Poncelet A, Hirsh D, Alliance for Clinical Education. Longitudinal integrated clerkships : principles, outcomes, practical tools, and future directions. 1st ed. North Syracuse: Gegensatz Press; 2016

44. Betancourt JR. Cross-cultural medical education: conceptual approaches and frameworks for evaluation. Acad Med. 2003;78(6):560-9.

45. Bird JB, Olvet DM, Willey JM, Brenner J. Patients don't come with multiple choice options: essay-based assessment in UME. Med Educ Online. 2019; 24(1):1649959

46. Lorde A. Learning from the 60s: Harvard University, Boston, Massachusetts; 1982. https://www.blackpast.org/african-american-history/1982-audre-lordelearning-60s/. Accessed 16 Feb 2021.

\section{Publisher's Note}

Springer Nature remains neutral with regard to jurisdictional claims in published maps and institutional affiliations.

Ready to submit your research? Choose BMC and benefit from:

- fast, convenient online submission

- thorough peer review by experienced researchers in your field

- rapid publication on acceptance

- support for research data, including large and complex data types

- gold Open Access which fosters wider collaboration and increased citations

- maximum visibility for your research: over $100 \mathrm{M}$ website views per year

At $\mathrm{BMC}$, research is always in progress.

Learn more biomedcentral.com/submissions 